\title{
STUDIES ON THE INACTIVATION METHODS OF THE VIRUS FOR PREPARATION OF RABIES VACCINE
}

\author{
TERUYA OKADA \\ The National Institute of Health, Tokyo, Japan
}

(Received: May 2nd, 1953)

\section{INTRODUCTION}

Recently, there have been a variety of improvements of inactivation method of rabies virus for the purpose of vaccine preparation, either by such physical treatment as ultraviolet irradiation(1) or high intensity electron(2), or with. such chemicals as nitrogen mustard(3) or merthiolate(4). Among them, merthiolate is reported to exert mild rabicidal action as compared with others above raised. It is of interest that such heavy metal compound when used in proper conditions, can produce potent vaccine. This fact led the author to the attempt. to find out whether or not a better vaccine can be produced by applying other agents, which are generally considered to be less rabicidal, to the inactivation procedure at lower temperature than $56^{\circ} \mathrm{C}$. Thus, some heavy-metal-salts and antimetabolites were used and satisfactory results were obtained. The present paper will discuss all these results with special reference to the postulated mechanisms of viral inactivation.

\section{MATERIALS AND Methods}

A fixed rabies virus, Nishigahara strain (brain to brain passage) was: employed in the experiments as either challenge virus for potency test or seed virus for production of vaccine. The guinea pig brain, infected with Nishigahara strain was harvested after the animal showed complete paralysis for 24 hours, and emulsified in buffer saline solution ( $\mathrm{pH}$ 7.0) by Waring blendor. The ten percent infected brain emulsion was used for the vaccine material.

Inactivation of the virus for vaccine preparation was made by heating for a certain period with formol, phenol, mercuric chloride, cobalt chloride, merthiolate, acridine-dye, acetosulfamine, marfanil and glycerol respectively.

A viability test with each lot of vaccine was made in 5 mice. Each 12-13. gram mouse was injected intracerebrally with $0.03 \mathrm{ml}$. All test mice were observed for 3 weeks, during which time, each mice should remain free of symptoms of fixed rabies virus or of other central nervous system diseases.

As for potency test, Habel's mouse protection test(6) was employed. 4 groups were used for virus dilutions in the test group and 3 groups for virus dilutions in the control group. The mice intended for the test group were respectively administrated $0.25 \mathrm{ml}$ of vaccine diluted to contain 0.5 percent brain 
tissue intraperitoneally every 2nd day, giving 6 doses in all. On the fourteenth day from the first dose of vaccine, the challenge dose was given to the immunized mice. They were divided into 4 groups and each group challenged intracerebrally with $0.03 \mathrm{ml}$ of $10^{-1}$ to $10^{-4}$ dilution respectively. The controls were divided into 3 groups and each group challenged intracerebrally with $0.03 \mathrm{ml}$ of $10^{-5}$ to $10^{-7}$ dilutions respectively. The 50 percent end-point was calculated by Reed and Muench's method.

\section{RESULTS}

(1) On the application of disinfectants such as formol, phenol, and mercuric chloride with heating at $37^{\circ} \mathrm{C}$ to inactivation of the virus for vaccine preparation.

The viral suspension was treated by heating at $37^{\circ} \mathrm{C}$ with such a disinfectant as formol, phenol, and mercuric chloride in its higher or lower concentration respectively, final concentrations of disinfectants were as follows: formol in 0.05 or 0.01 percent, phenol in 0.5 or 0.25 percent, and mercuric chloride in 0.1 or 0.01 percent.

Each of such treated viral suspensions was completely inactivated for 5 to 7 days respectively. A potency test with each of those inactivated vaccine was shown in Table 1.

Table 1. Comparison of potency with each lot of vaccine inactivated by incubating at $37^{\circ} \mathrm{C}$ with each disinfectant respectively

\begin{tabular}{|c|c|c|c|c|c|c|c|c|c|c|c|}
\hline \multirow{2}{*}{ Vaccines } & \multirow{2}{*}{$\begin{array}{l}\text { Concent- } \\
\text { ration of } \\
\text { disinfec- } \\
\text { tants }\end{array}$} & \multirow{2}{*}{$\mathrm{pH}$} & \multicolumn{7}{|c|}{ Dilutions of challenge virus } & \multirow{2}{*}{$\mathrm{LD}_{50}$} & \multirow{2}{*}{$\begin{array}{l}\text { Protective } \\
\text { value }\end{array}$} \\
\hline & & & -1 & -2 & -3 & -4 & -5 & -6 & -7 & & \\
\hline \multirow{2}{*}{$\begin{array}{l}\text { Mercuric } \\
\text { chloride-V. }\end{array}$} & $0.1 \%$ & $|7.1|$ & & & $5 / 5^{*}$ & $\mid 5 / 5$ & $|3 / 5|$ & $1 / 5$ & & $10^{-5.3}$ & $8 \mathrm{MLD}$ \\
\hline & $0.01 \%$ & 7.0 & $4 / 5$ & $2 / 5$ & $0 / 5$ & $0 / 5$ & & & & $10^{-1.7}$ & $3 \times 10^{4} \quad M L D$ \\
\hline \multirow{2}{*}{ Formol-V. } & $0.05 \%$ & 6.8 & $5 / 5$ & $5 / 5$ & $4 / 5$ & $|3 / 5|$ & & & & $<10^{-4.0}$ & $<2 \times 10^{2} \mathrm{MLD}$ \\
\hline & $0.01 \%$ & 7.0 & $2 / 5$ & $1 / 5$ & $1 / 5$ & $0 / 5$ & & & & $10^{-1.2}$ & $10^{5} \mathrm{MLD}$ \\
\hline \multirow{2}{*}{ Phenol-V. } & $0.5 \%$ & 6.8 & $5 / 5$ & $5 / 5$ & $4 / 5$ & $3 / 5$ & & & & $<10^{-4.0}$ & $<2 \times 10^{2} \mathrm{MLD}$ \\
\hline & $0.25 \%$ & 7.0 & $3 / 5$ & $1 / 5$ & $0 / 5$ & $\mid 0 / 5$ & & & & $10^{-1.3}$ & $8 \times 10^{4} \mathrm{MLD}$ \\
\hline Control & & & & & & & $5 / 5$ & $3 / 5$ & $0 / 5$ & $10^{-6.2}$ & \\
\hline
\end{tabular}

Virulence of the brain used for production of the vaccines: $L_{50}=10^{-6.5}$

* Numerator: number of deaths

Denominator: number of total mice

As shown in Table 1, when such a disinfectant as formol, phenol, and mercuric chloride was applied to inactivation of virus with incubation at $37^{\circ} \mathrm{C}$, there showed the marked difference of potency between both vaccines treated with its high and low concentration. The higher the concentration of disinfectants used, the more the destruction of antigenicity was observed; the parallel relationship 
between the concentration of a disinfectant and the destruction of antigenicity was observed. It may be, therefore, concluded that in this case the possibly low concentration of a disinfectant for preparation of potent vaccine should be used,

(2) On the inactivation of the infected brain tissue emulsified in 50 percent glycerol by incubating at $37^{\circ} \mathrm{C}$.

In order to examine the thermal effect on the viral suspension without the cooperation of any other inactivating agent, the next experiment was made. The viral suspension without the addition of any substance was incubated at $37^{\circ} \mathrm{C}$ for $3,5,7$, and 9 days respectively. Both results of a viability test with each of such treated suspension respectively and of a potency test with such completed vaccine were shown in Table $2(\mathrm{~A})$ and $(\mathrm{B})$.

Table 2. Inactivation of the infected brain tissue emulsified in $50 \%$ glycerol by heating at $37^{\circ} \mathrm{C}$

(A) A viability test with the viral suspension incubated at $37^{\circ} \mathrm{C}$ for $3,5,7$, and 9 days respectively

\begin{tabular}{l|c|c|c|c}
\hline Days of incubation & 3 days & 5 days & 7 days & 9 days \\
\hline Viability tests & $5 / 5$ & $4 / 5$ & $2 / 5$ & $0 / 5$
\end{tabular}

(B) A potency test with the vaccine

\begin{tabular}{l|c|c|c|c|c|c|c|c|c|c}
\hline & \multirow{2}{*}{} & \multicolumn{6}{|c|}{ Dilutions of challenge virus } & \multirow{2}{*}{$\mathrm{LD}_{50}$} & $\begin{array}{c}\text { Protective } \\
\text { value }\end{array}$ \\
\cline { 2 - 9 } & & -1 & -2 & -3 & -4 & -5 & -6 & -7 & & \\
\hline Vaccine & 7.0 & $4 / 5$ & $2 / 5$ & $0 / 5$ & $0 / 5$ & & & & $10-1.7$ & $6 \times 10^{4} \mathrm{MLD}$ \\
\hline Control & & & & & & $5 / 5$ & $4 / 5$ & $1 / 5$ & $10-6.5$ &
\end{tabular}

See foot-note of Table $1 . \mathrm{LD}_{50}=10^{-5.3}$

As shown in Table 2, complete inactivation of the viral suspension was obtained in no longer than 9 days by incubating at $37^{\circ} \mathrm{C}$ without the addition of any other agent, and such treated vaccine showed the high potency of 60,000 MLD protective value. Therefore, incubation at $37^{\circ} \mathrm{C}$ is considered to be an extremely mild inactivating procedure of the virus with little or no destruction of antigenicity for preparation of potent rabies vaccine.

(3) On the significance of merthiolate and heating on merthiolate (merzonin) vaccine.

One cannot overlook the fact that merthiolate was used as an inactivating agent of the virus for vaccine preparation by Dr. Yaoi ${ }^{(4)}$, but that at the same time, incubation at $37^{\circ} \mathrm{C}$ for a certain period was also an indispensable factor of inactivating the virus. Therefore, in order to determine the significance of merthiolate and heating on inactivation of the virus for vaccine preparation, the next experiment was made. 
One was inactivated by merthiolate $(0.1 \%)$ at $37^{\circ} \mathrm{C}, 42^{\circ} \mathrm{C}$ and $56^{\circ} \mathrm{C}$ respectively; the other was done alone by heating at $37^{\circ} \mathrm{C}, 42^{\circ} \mathrm{C}$ and $56^{\circ} \mathrm{C}$ respectively and then added with merthiolate. The results of comparisons of viability and potency tests with both types of vaccines treated by such different procedures were shown in Table $3(\mathrm{~A})$ and $(\mathrm{B})$.

Table 3. Inactivation of the viral suspension with merthiolate before and after heating at $37^{\circ} \mathrm{C}, 42^{\circ} \mathrm{C}$ and $56^{\circ} \mathrm{C}$ respectively

(A) A viability test with each lot of vaccine

\begin{tabular}{c|c|c|c}
\hline \multirow{2}{*}{ Temperature } & $\begin{array}{c}\text { Merthiolate } \\
(0.1 \text { percent })\end{array}$ & $\begin{array}{c}\text { Periods required } \\
\text { for inactivation }\end{array}$ & $\mathrm{pH}$ \\
\hline \multirow{2}{*}{$37^{\circ} \mathrm{C}$} & before & 5 days & 6.8 \\
\cline { 2 - 4 } & after & 7 days & 6.8 \\
\hline \multirow{2}{*}{$42^{\circ} \mathrm{C}$} & before & 2 days & 7.0 \\
\cline { 2 - 4 } & after & 2 days & 7.0 \\
\hline \multirow{2}{*}{$56^{\circ} \mathrm{C}$} & before & $1 / 2$ hour & 7.0 \\
\cline { 2 - 4 } & after & $1 / 2$ hour & 7.0 \\
\hline
\end{tabular}

(B) A potency test with each lot of vaccine

\begin{tabular}{|c|c|c|c|c|c|c|c|c|c|c|}
\hline \multirow{2}{*}{ Vaccines } & \multirow{2}{*}{$\mathrm{pH}$} & \multicolumn{7}{|c|}{ Dilutions of challenge virus } & \multirow{2}{*}{$\mathrm{LD}_{50}$} & \multirow{2}{*}{$\begin{array}{l}\text { Protective } \\
\text { value }\end{array}$} \\
\hline & & -1 & -2 & -3 & -4 & -5 & -6 & -7 & & \\
\hline \multirow{2}{*}{$\begin{array}{c}\text { before } \\
\text { Merthiolate } \cdots \cdots \cdots \cdots \cdot 37^{\circ} \mathrm{C} \\
\text { after }\end{array}$} & 6.8 & $3 / 5$ & $1 / 5$ & $0 / 5$ & $0 / 5$ & & & & $10^{-1.3}$ & $10^{5} \mathrm{MLD}$ \\
\hline & 6.8 & $4 / 5$ & $2 / 5$ & $0 / 5$ & $0 / 5 \mid$ & & & & $10^{-1.7}$ & $4 \times 10^{4} \quad M L D$ \\
\hline \multirow{2}{*}{$\begin{array}{c}\text { before } \\
\text { Merthiolate } \cdots \cdots \cdots, 2^{\circ} \mathrm{C} \\
\text { after }\end{array}$} & 7.0 & $5 / 5$ & $2 / 5$ & $0 / 5$ & $0 / 5$ & & & & $10^{-1.8}$ & $3 \times 10^{4} \mathrm{MLD}$ \\
\hline & 7.0 & $4 / 5$ & $2 / 5$ & $0 / 5$ & $0 / 5$ & & & & $10-1.7$ & $4 \times 10^{4} \mathrm{MLD}$ \\
\hline \multirow{2}{*}{$\begin{array}{c}\text { before } \\
\text { Merthiolate } \cdots \cdots \cdots \cdot 56^{\circ} \mathrm{C} \\
\text { after }\end{array}$} & 7.0 & $5 / 5$ & $2 / 5$ & $1 / 5$ & $0 / 5$ & & & & $10-2.0$ & $2 \times 10^{4}$ MLD \\
\hline & 7.0 & $5 / 5$ & $3 / 5$ & $0 / 5$ & $0 / 5$ & & & & $10-2.2$ & $10^{4} \mathrm{MLD}$ \\
\hline Control & & & & & & $5 / 5$ & $3 / 5$ & $1 / 5$ & $10-5.3$ & \\
\hline
\end{tabular}

See foot-note of Table $1 . \mathrm{LD}_{50}=10-5.6$

(4) On the in vitro rabicidal effect of some chemicals.

In order to examine the in vitro rabicidal effect of bacteriostatic agents: which may be generally supposed to be less antiviral, as compared with bactericidal agents, the next experiment was made. The in vitro antiviral effects of disinfectants such as formol, phenol, and mercuric chloride in relatively low concentration, heavy-metal-salts such as merthiolate and cobalt chloride, sulfadrugs such as acetosulfamine and marfanil, and acridine-dye in relatively high 
concentration as compared with their minimal antibacterial concentrations. Each of those chemicals was added in equal volume to the supernatant fluid from $20 \%$ viral suspension centrifuged for 10 minutes at 2,000 r.p.m.. The titration tests of the still alive virus in the mixtures, after kept at $5^{\circ} \mathrm{C}$ for 24 hours, were made.

Table 4. Effect of some chemicals upon the infectivity of the viral suspension

\begin{tabular}{|c|c|c|c|c|c|c|c|c|c|c|c|}
\hline \multirow{2}{*}{$\begin{array}{c}\text { Chemicals } \\
\text { (antibac- } \\
\text { terial) }\end{array}$} & \multirow{2}{*}{$\begin{array}{c}\text { Concent- } \\
\text { rations of } \\
\text { preserva- } \\
\text { tives }\end{array}$} & \multirow{2}{*}{\begin{tabular}{|c|}
$\mathrm{pH}$ of \\
vac- \\
cines
\end{tabular}} & \multicolumn{7}{|c|}{ Dilutions of challenge virus } & \multirow{2}{*}{$\mathrm{LD}_{50}$} & \multirow{2}{*}{$\begin{array}{l}\text { Reduction of } \\
\text { infectivity }\end{array}$} \\
\hline & & & -1 & -2 & -3 & -4 & -5 & -6 & -7 & & \\
\hline Acridine-dye & $0.25 \%$ & 7.0 & & & & $5 / 5$ & $5 / 5$ & $1 / 5$ & & $10-5.6$ & $5 \mathrm{MLD}$ \\
\hline Acetosulfamine & $15 \%$ & 8.0 & & & & $5 / 5$ & $4 / 5$ & $1 / 5$ & & $10^{-5.5}$ & $6 \mathrm{MLD}$ \\
\hline Marfanil & $15 \%$ & 6.2 & & & & $5 / 5$ & $2 ; 5$ & $0 / 5$ & & $10-4.3$ & $10^{2} \mathrm{MLD}$ \\
\hline Merthiolate & $1 \%$ & 6.6 & & & & $5 / 5$ & $3 / 5$ & $1 / 5$ & & $10-5.3$ & 10 MLD \\
\hline Cobalt chloride & $1 \%$ & 5.6 & & & $5 / 5$ & $3 / 5$ & $1 / 5$ & & & $10^{-4.3}$ & $10^{2} \cdot \mathrm{MLD}$ \\
\hline Cobalt chloride & $0.5 \%$ & 6.2 & & & $5 / 5$ & $5 ; 5$ & $1 / 5$ & & & $10^{-4.6}$ & 50 MLD \\
\hline Mercuric chloride & $0.1 \%$ & 6.6 & $5 / 5$ & $3 / 5$ & $0 / 5$ & & & & & $10^{-2.2}$ & $10^{4} \mathrm{MLD}$ \\
\hline Formol & $0.1 \%$ & 6.8 & $5 / 5$ & $4 / 5$ & $0 / 5$ & & & & & $10^{-2.4}$ & $8 \times 10^{3} \mathrm{MLD}$ \\
\hline Phenol & $0.5 \%$ & 6.8 & & & $5 / 5$ & $4 / 5$ & $1 / 5$ & & & $10-5.0$ & $20 \mathrm{MLD}$ \\
\hline Control & & & & & & & $5 / 5$ & $3 / 5$ & $1 / 5$ & $10-6.3$ & \\
\hline
\end{tabular}

See foot-note of Table 1.

Formol and mercuric chloride in relatively low concentration reduced the infective titre of virus by ca 10,000 MLD, but the other agents by less than 100 MLD; the former chemicals were more rabicidal than the latter ones. It may be, therefore, concluded that the latter chemicals are hardly rabicidal.

(5) On the prolonged inactivation of viral suspension by incubating at $37^{\circ} \mathrm{C}$ with each above-raised chemical respectively.

The mild inactivation of viral suspension by incubating at $37^{\circ} \mathrm{C}$ with each of chemicals which were proved to be weakly rabicidal, respectively, was undertaken. Both results of a viability test with each lot of the viral suspension treated with each of them, incubated at $37^{\circ} \mathrm{C}$ for $3,5,7$, and 9 days respectively and of a potency test with each lot of such completed vaccines were shown in Table 5 and 6. Furthermore, the thermostability and preservability of those vaccines were examined. The thermostability of vaccine was determined by its resistance to further 30 day's incubation at $37^{\circ} \mathrm{C}$ after complete inactivation of the virus, and the preservability, by its resistance to one year's storage at $5^{\circ} \mathrm{C}$. These results were shown in Table 7 and 8 .

As shown in Table 5, the viral suspension, when incubated at $37^{\circ} \mathrm{C}$ with each above, raised chemical respectively, was so mildly inactivated that the complete inactivation required as long as 7-9 days.

As each of such treated vaccines protected against 100,000 MLD, such procedure may be considered to be suitable for vaccine preparation. 
Table 5. A viability test with each lot of the viral suspension incubated at $37^{\circ} \mathrm{C}$ with each chemical (antibacterial) respectively

\begin{tabular}{l|r|r|r|r|r|r|c|c}
\hline \multirow{2}{*}{ Chemicals } & $\begin{array}{c}\text { Concent- } \\
\text { rations of } \\
\text { chemicals }\end{array}$ & \multicolumn{5}{|c|}{ Days of inactivation } & $\begin{array}{c}\text { pH of } \\
\text { suspen- } \\
\text { sions }\end{array}$ \\
\hline Acridine-dye & $0.025 \%$ & $5 / 5$ & $5 / 5$ & $2 / 5$ & $0 / 5$ & & 7.0 \\
Acetosulfamine & $3 \%$ & $5 / 5$ & $5 / 5$ & $3 / 5$ & $0 / 5$ & & 7.0 \\
Marfanil & $3 \%$ & $5 / 5$ & $5 / 5$ & $1 / 5$ & $0 / 5$ & & 6.6 \\
Merthiolate & $0.1 \%$ & $5 / 5$ & $5 / 5$ & $1 / 5$ & $0 / 5$ & & 6.6 \\
Cobalt chloride & $0.1 \%$ & $5 / 5$ & $5 / 5$ & $2 / 5$ & $0 / 5$ & & 6.6 \\
Mercuric chloride & $0.01 \%$ & $5 / 5$ & $2 / 5$ & $0 / 5$ & & & 6.6 \\
Formol & $0.01 \%$ & $5 / 5$ & $2 / 5$ & $0 / 5$ & & & 6.7 \\
Phenol & $0.5 \%$ & $5 / 5$ & $5 / 5$ & $0 / 5$ & & & 6.8 \\
Glycerol & $50 \%$ & $5 / 5$ & $5 / 5$ & $5 / 5$ & $2 / 5$ & $0 / 5$ & 7.0
\end{tabular}

See foot-note of Table 1. $\mathrm{LD}_{50}=10^{-6.7}$

Table 6. A potency test with each lot of inactivated vaccine

by incubating at $37^{\circ} \mathrm{C}$ with each above raised chemical respectively

\begin{tabular}{|c|c|c|c|c|c|c|c|c|c|c|c|}
\hline \multirow{2}{*}{ Vaccines } & \multirow{2}{*}{$\begin{array}{l}\text { Concent- } \\
\text { ration of } \\
\text { preserva- } \\
\text { tives }\end{array}$} & \multirow{2}{*}{$\begin{array}{c}\mathrm{pH} \text { of } \\
\text { vac- } \\
\text { cines }\end{array}$} & \multicolumn{7}{|c|}{ Dilutions of challenge virus } & \multirow{2}{*}{$\mathrm{LD}_{50}$} & \multirow{2}{*}{$\begin{array}{l}\text { Protective } \\
\text { value }\end{array}$} \\
\hline & & & -1 & -2 & -3 & -4 & -5 & -6 & -7 & & \\
\hline Acridine-dye V. & $0.025 \%$ & 7.0 & $2 / 5$ & $1 / 5$ & $1 / 5$ & & & & & $10-1.2$ & $5 \times 10^{5} \mathrm{MLD}$ \\
\hline Acetosulfamine V. & $3 \%$ & 7.2 & $2 / 5$ & $0 / 5$ & $0 / 5$ & & & & & $>10-0.8$ & $>8 \times 10^{5} \mathrm{MLD}$ \\
\hline Marfanil V. & $3 \%$ & 6.8 & $1 / 5$ & $0 / 5$ & 0,5 & & & & & $>10-0.6$ & $>10^{6} \mathrm{MLD}$ \\
\hline Cobalt chloride V. & $0.1 \%$ & 6.6 & $1 / 5$ & $1 / 5$ & $0 / 5$ & & & & & $>10-0.8$ & $>8 \times 10^{5} \mathrm{MLD}$ \\
\hline $\begin{array}{l}\text { Glycerol V. } \\
\text { Control }\end{array}$ & $50 \%$ & 7.0 & $2 / 5$ & $1 / 5$ & 0,5 & & $5 / 5$ & $3 / 5$ & $2 / 5$ & $\begin{array}{l}10-1.0 \\
10-6.5\end{array}$ & $7 \times 10^{5} \mathrm{MLD}$ \\
\hline
\end{tabular}

See foot-note of Table $1 . \quad L_{50}=10^{-6.8}$

Table 7. Influence of 30 days' heating at $37^{\circ} \mathrm{C}$ upon each lot of vaccine

\begin{tabular}{|c|c|c|c|c|c|c|c|c|c|c|c|}
\hline \multirow{2}{*}{ Vaccines } & \multirow{2}{*}{$\begin{array}{l}\text { Concent- } \\
\text { rations of } \\
\text { preser- } \\
\text { vatives }\end{array}$} & \multirow{2}{*}{$\begin{array}{c}\mathrm{pH} \text { of } \\
\text { vac- } \\
\text { cines }\end{array}$} & \multicolumn{7}{|c|}{ Dilutions of challenge virus } & \multirow{2}{*}{$\mathrm{LD}_{50}$} & \multirow{2}{*}{$\begin{array}{l}\text { Protective } \\
\text { value }\end{array}$} \\
\hline & & & -1 & -2 & $|-3|$ & -4 & -5 & -6 & -7 & & \\
\hline Acridine-dye V. & $0.025 \%$ & 7.0 & & & & $4 / 5$ & $2 / 5$ & 0,5 & & $10-4.7$ & 90 MLD \\
\hline Acetosulfamine $\mathrm{V}$. & $3 \%$ & 7.5 & & & $5 / 5$ & $3 / 5$ & 0,5 & & & $10-4.2$ & $5 \times 10^{2} \mathrm{MLD}$ \\
\hline Marfanil V. & $3 \%$ & 6.8 & & & $4 / 5$ & $2 / 5$ & $0 / 5$ & & & $1 C^{-3.7}$ & $9 \times 10^{2} \mathrm{MLD}$ \\
\hline Cobalt chloride V. & $0.1 \%$ & 6.6 & & & $5 / 5$ & $2 / 5$ & $1 / 5$ & & & $10^{-4.0}$ & $7 \times 10^{2} \mathrm{MLD}$ \\
\hline Glycerol V. & $50 \%$ & 7.0 & & & 5,5 & 2,5 & $0 / 5$ & & & $1 C^{-3.8}$ & $8 \times 10^{2} \mathrm{MLD}$ \\
\hline Control & & & & & & & $5 / 5$ & 3,5 & $2 / 5$ & $1 C-6.5$ & \\
\hline
\end{tabular}

See foot-note of Table 1. $\mathrm{LD}_{50}=10-6.5$

Each of those vaccines was capable of standing 100-1,000 MLD even by such drastic procedure; this suggests that they may be considered to be relatively thermostable, because such drastic procedure is generally believed to induce the complete loss of antigenicity. 
Table 8. Comparison of potency with each lot of vaccine which was stored at $5^{\circ} \mathrm{C}$ for one month and one year respectively

\begin{tabular}{|c|c|c|c|c|c|}
\hline Vaccines & \multicolumn{5}{|c|}{ Protective value } \\
\hline $\begin{array}{l}\text { Period } \\
\text { of stor- } \\
\text { age at } 5^{\circ} \mathrm{C}\end{array}$ & $\begin{array}{c}\text { Acridine-dye } \\
\text { V. }\end{array}$ & $\begin{array}{l}\text { Cobalt } \\
\text { chloride V. }\end{array}$ & $\begin{array}{l}\text { Acetosul- } \\
\text { famine V. }\end{array}$ & Marfanil V. & Glycerol V. \\
\hline One month & $7 \times 10^{4} \mathrm{MLD}$ & $2 \times 10^{6} \mathrm{MLD}$ & $3 \times 10^{6} \mathrm{MLD}$ & $5 \times 10^{6} \mathrm{MLD}$ & $8 \times 10^{5} \mathrm{MLD}$ \\
\hline One year & $2 \times 10^{3} \mathrm{MLD}$ & $4 \times 10^{4} \mathrm{MLD}$ & $6 \times 10^{4} \mathrm{MLD}$ & $2 \times 10^{5} \mathrm{MLD}$ & $5 \times 10^{4} \mathrm{MLD}$ \\
\hline
\end{tabular}

See foot-note of Table $1 . \mathrm{LD}_{05}=10^{-6.8}$

As shown in Table 8, each of those vaccines was capable of standing 1,000 MLD, even if kept at $5^{\circ} \mathrm{C}$ for one year, with loss of its antigenicity than that of formol or phenol one; this suggests that they may be preservable for as long as one year.

(6) Comparison of potency with each lot of those vaccines by modified Habel's test methods.

Firstly, in order to examine the possibility for removal of brain tissue to some extent with the possibly little reduction of antigenicity, the supernatant fluid centrifuged for 10 minutes at 2,000 r.p.m., instead of the crude material of each vaccine was used....B method. Secondly, in order to examine the possibility for keeping almost the same protective titre as that by orthodox method with the possibly little dose or few frequency of inoculation, the former 3 doses, instead of the 6 doses were used....C method. Thirdly, in order to test the possibly early immune response of protecting against 1,000 MLD, the challenge test was made on the seventh, instead of the fourteenth day after the first dose.... D method. As A method, orthodox Habel's test was made. The results of all these tests with each lot of those vaccines were shown in Table 9.

Table 9. Comparison of potency with each lot of vaccine by the modified Habel's test methods

\begin{tabular}{c|l|l|l|l|l}
\hline $\begin{array}{c}\text { Test Vaccines } \\
\text { Methods }\end{array}$ & Acridine-dye & $\begin{array}{c}\text { Acetosul- } \\
\text { famine }\end{array}$ & Marfanil & \multicolumn{1}{|c}{$\begin{array}{c}\text { Cobalt } \\
\text { chloride }\end{array}$} & \multicolumn{1}{|c|}{ Glycerol } \\
\hline A Method & $6 \times 10^{4}$ MLD & $7 \times 10^{5}$ MLD & $10^{6}$ MLD & $2 \times 10^{6}$ MLD & $9 \times 10^{5}$ MLD \\
B Method & $2 \times 10^{3}$ MLD & $2 \times 10^{4}$ MLD & $5 \times 10^{4}$ MLD & $7 \times 10^{3}$ MLD & $3 \times 10^{4}$ MLD \\
C Method & $5 \times 10^{4}$ MLD & $10^{5}$ MLD & $3 \times 10^{5}$ MLD & $5 \times 10^{5}$ MLD & $3 \times 10^{4}$ MLD \\
D Method & $3 \times 10^{3}$ MLD & $3 \times 10^{4}$ MLD & $10^{3}$ MLD & $2 \times 10^{4}$ MLD & $5 \times 10^{3}$ MLD
\end{tabular}

Virulence of the brain, used for production of the vaccines: $L_{50}=10-6.5$

Each of those vaccines, when used with the former 3 doses, almost the same potency of ca 100,000 MLD, protective value, but when tested on the seventh day after the first vaccination, or used with the supernatant fluid, the lower potency of $1,000-10,000$ MLD protective value, as compared with the result of the orthodox method. 
They showed the early immune response, the sufficient immune effect of the little dose, and the possibility for removal of barin tissue from vaccine to some extent. This suggests that these advantages may be satisfactory for clinical application. It may be, therefore, concluded that all these advantages are, after all, due to the vaccines' high potency.

(7) On the development of rabicidal antibodies in guinea pigs following the intradermal inoculation of each lot of the vaccines.

According to Dr. Yaoi( ${ }^{(4)}$, each lot of the vaccines was injected intradermally 0.2 cc each daily for seven days.

A neutralization test with each serum drawn on the 7 th, 14th, and 21 st day after the first vaccination respectively was made. The results of neutralization tests on each serum were shown in Table 10.

Table 10. A neutralization test with each lot of serum drawn on the 7th-, 14th-, and 21st-day after the first dose respectively

\begin{tabular}{|c|c|c|c|c|}
\hline \multicolumn{5}{|c|}{ Protective value } \\
\hline Serum $\begin{array}{c}\text { Vaccines } \\
\text { tested }\end{array}$ & $\begin{array}{c}\text { Cobalt } \\
\text { chloride V. } \\
*(0.0 \%)\end{array}$ & $\underset{(0.025 \%)}{\text { Acridine-dye } V .}$ & $\begin{array}{l}\text { Acetosul- } \\
\text { famine V } \\
(3 \%)\end{array}$ & $\underset{(3 \%)}{\text { Marfanil }} \mathrm{V}$ \\
\hline 7th day & $30 \mathrm{MLD}$ & $10 \mathrm{MLD}$ & $2 \times 10^{2} \mathrm{MLD}$ & $5 \times 10^{2} \mathrm{MLD}$ \\
\hline 14th day & $2 \times 10^{3} \mathrm{MLD}$ & $5 \times 10^{3} \mathrm{MLD}$ & $8 \times 10^{3} \mathrm{MLD}$ & $2 \times 10^{4} \mathrm{MLD}$ \\
\hline 21st day & $8 \times 10^{3} \mathrm{MLD}$ & $3 \times 10^{3} \mathrm{MLD}$ & $10^{4} \mathrm{MLD}$ & $7 \times 10^{3} \mathrm{MLD}$ \\
\hline
\end{tabular}

See foot-note of Table 1. $L D_{50}=10^{-6.6}$

* concentration of a chemical

Each antiserum drawn either on the 14th or 21st day after the first vaccination, showed 1,000-10,000 MLD neutralization value. When each of these vaccines was used by such procedure, $1.4 \mathrm{cc}$ in total seems sufficient to protect against the infection and development of rabies in guinea pigs; this suggests that those vaccines may be used to the effect by such procedure.

\section{Discussion}

Formol or phenol, which has so far been widely used as an inactivating agent of rabies virus for vaccine preparation, serves also as a preservative. The higher its concentration is, the stronger its rabicidal effect is, but at the same time, the more the extent is, to which the destruction of antigenicity takes place (Table 1). It is of great interest that inactivation of virus with merthiolate was completed in 5 days, while it needed a week or more without the addition of it, and that in both cases the inactive virus retained its antigenicity to almost equal extent (Table 3). It might be, therefore, that thermal degradation of virus plays main role in the inactivation and the addition of such a chemical as merthiolate serves mostly to prevent bacterial contamination and to enhance or accelerate the thermal effect. 
One will sometimes find difficulty in obtaining the steril viral suspension, when incubated at $37^{\circ} \mathrm{C}$, without addition of any antibacterial agent. Therefore, the addition of some antibacterial agent which induces little or no destruction of antigenicity, is indispensable to inactivation of the virus for vaccine preparation by such procedure. For this purpose, merthiolate is widely used as a preservative. This is presumably due to the fact that it being inactivated by SH compounds $(7)$ is a bacteriostatic agent within the certain range of concentration; it is generally used in its bacteriostatic concentration as a preservative. This led the author to the idea that bacteriostatic agents such as sulfa-drugs or related compounds may be applied as substitutes for merthiolate. It may be generally supposed that series of bacteriostatic agents are hardly rabicidal, while a series of bactericidal agents are rabicidal.

This was proved by the observation that when merthiolate was replaced by some of sulphonamides or heavy-metal-salts, more potent vaccine was obtained in either case than by formol or phenol (Table 6). Another and more important merit of it was its capability of keeping the antigenicity with relatively less severe damage even after such drastic procedure as one month's incubation at $37^{\circ} \mathrm{C}$ (Table 7). From this fact it can be easily supposed, for the first place, that its antigenicity is relatively thermostable and secondly that some of antimetabolites as well as heavy-metal-salts, at least within the range of concentration used here, have less marked influence upon the retainment of viral antigenicity than formol or phenol.

One might draw the generalization that the milder rabicidal effect an inactivating agent possesses, the higher potency, the more thermostability and the longer preservation period can be expected when it is used in heating procedure of vaccine preparation.

It is of interest that heating at lower temperature than $56^{\circ} \mathrm{C}$ is rabicidal but weakly bactericidal, while the bacteriostatic agents are hardly rabicidal, and that both agents induce little or no destruction of antigenicity. This led the author to the idea that potent vaccine can be produced by combined effects of both agents.

\section{CONCLUSIONS}

(1) When such a disinfectants as formol, phenol, and mercuric chloride was applied to inactivation of rabies virus with heating at $37^{\circ} \mathrm{C}$, the lower the concentration was, the better effect on the retainment of antigenicity of the vaccine was afforded.

(2) Each lot of the vaccines inactivated by heating at $37^{\circ} \mathrm{C}$ with either acridine-dye, acetosulfamine, marfanil or cobalt chloride which were hardly rabicidal, was highly potent, relatively thermostable, and preservable for a period of more than one year.

(3) Heating at different temperatures lower than $56^{\circ} \mathrm{C}$ without addition of any substance also resulted in obtaining satisfactorily potent vaccine. 
Acknowledgements: I am indebted to Dr. A. Kondo for his cordial cooperation. I also wish to express my appreciation to Dr. M. Kitaoka and Dr. H. Yaoi for their constant advice and encouragement.

\section{REFERENCES}

(1) Habel, K.: Ultraviolet irradiation in the production of potent anti-rabies vaccines. Pub. Health Rep. 62 (22): 791-800, 1947.

(2) Traub, F. B., Friedemann, U., Brasch, A. \& Huber, W. High Intensity Electrons as a tool for preparation of vaccines.

1. Preparation of Rabies Vaccine

J. Immunology, 1951, Nov., V. 67, No. 5, 379-84

(3) Tembroeck, C. and Herriott, R. M.: Mustard Inactivated Rabies Vaccine. Proceedings of the Society for Experimental Biology and Medicine, 1950, V. $75,523-528$.

(4) Yaoi, H.: On a new anti-rabies vaccine, inactivated completely by Merzonin and heat. Yokohama Medical Bulletin, Vol. 1, pp. 15-25, 1950.

(5) Method for Production of Rabies Vaccine Michigan Department of Health.

(6) Habel, K.: Evaluation of mouse test for the standardization of the immunizing power of anti-rabies vaccines. Pub. Health Rep. 55: 1475-1487, 1940.

(7) Akiba, T. and Ishii, K.: On the mode of action of mercuric compounds (I) (II). Jap. J. of Bacteriology Vol. 5 No. 1, 27-29, 1950. 